\title{
Undernutrition in utero increases susceptibility to prostate neoplasias in adult rat after steroid exposure
}

\author{
Jaqueline C Rinaldi', Sérgio L Felisbino \\ From São Paulo Advanced School of Comparative Oncology \\ Águas de São Pedro, Brazil. 30 September - 6 October 2012
}

\section{Background}

Maternal protein restriction during pregnancy promotes several alterations in the progeny. Previous studies showed that androgen/estrogen imbalances during perinatal period, can program prostate cells to develop prostate lesions in adult life after a second insult. This study aimed to investigate prostate diseases susceptibility in adult rat offspring which underwent in utero low protein diet and were chronically exposed to low doses of estrogen and testosterone in adult life.

\section{Material and methods}

16 weeks-old Wistar rats $(\mathrm{n}=48)$ that received in utero normal protein diet (NP group, 17\% protein) or low protein diet (LP group, $6 \%$ protein) were subjected to 17 -beta estradiol+testosterone administration (subcutaneous implant, NPH and LPH groups) for 16 weeks. The animals were killed at age of 35 week and the ventral (VP) and dorsolateral prostate (DLP) was excised, weighted and processed for histochemical, morphometrical and immunohistochemical (AR, Ki67, p63, beta-catenin, laminin and GSTP) analyses.

\section{Results}

Both VP and DLP weight from NPH group were higher than LPH group. Serological data showed that estradiol levels were similar in both groups, but testosterone levels were lower in the LPH male offspring. Morphometric analysis verified a decrease in the height of prostatic epithelium, apoptotic index and an increase of proliferation index in LPH group compared to NPH group. The incidence of prostatitis and prostatic intraepithelial neoplasia

\footnotetext{
* Correspondence: jcrinaldi@ibb.unesp.br
}

Morphology Department, UNESP - Sao Paulo State University, Botucatu, SP, Brazil

\section{BioMed Central}

(0) 2013 Rinaldi and Felisbino; licensee BioMed Central Ltd. This is an Open Access article distributed under the terms of the Creative Commons Attribution License (http://creativecommons.org/licenses/by/2.0), which permits unrestricted use, distribution, and reproduction in any medium, provided the original work is properly cited. was higher in VP and DLP of LPH group. However prostate cancer was not observed.

\section{Conclusion}

Maternal protein restriction alters adult prostate response to androgen/estrogen handling and also interferes in adult prostate susceptibility to diseases.

\section{Financial support}

FAPESP (2009/50204-6).

Published: 4 April 2013

doi:10.1186/1753-6561-7-S2-P32

Cite this article as: Rinaldi and Felisbino: Undernutrition in utero

increases susceptibility to prostate neoplasias in adult rat after steroid exposure. BMC Proceedings 2013 7(Suppl 2):P32.

Submit your next manuscript to BioMed Central and take full advantage of:

- Convenient online submission

- Thorough peer review

- No space constraints or color figure charges

- Immediate publication on acceptance

- Inclusion in PubMed, CAS, Scopus and Google Scholar

- Research which is freely available for redistribution

Submit your manuscript at 